\title{
Infarction of the unilateral posterior horn and lateral column of the spinal cord with sparing of posterior columns: demonstration by MRI
}

\author{
Masao Kaneki, Kiyoharu Inoue, Teruo Shimizu, Toru Mannen
}

\begin{abstract}
Infarction of the spinal cord, particularly in the distribution of the posterior spinal arteries, is rare. Twenty seven cases of posterior spinal artery syndrome have been reported. In all cases, the posterior columns were affected, and in all but two, the lesions were bilateral. Here a 49year-old woman is reported, who was affected with lumbar cord infarction in the distribution of the posterior spinal arteries, diagnosed by MRI and clinical presentation. This case is of special interest because of sparing of the posterior columns and the unilateral nature of the lesion, even though the infarction occurred in the distribution of the posterior spinal arteries.
\end{abstract}

$(F$ Neurol Neurosurg Psychiatry 1994;57:629-631)

Posterior spinal artery syndrome is rarely described. To our knowledge, twenty seven cases have been reported in English, ${ }^{1-7}$ French, ${ }^{8-13}$ German, ${ }^{14-16}$ and Japanese publications. ${ }^{1718}$ These reports indicate that posterior spinal artery syndrome has a variable clinical presentation and distribution of the injury and is not thought to occur in a "pure" form because of its complicated anastomotic network. ${ }^{6919}$ In all these cases, however, the posterior columns were affected, so that disturbance of deep sensibility has been believed to be cardinal. ${ }^{19}$ All cases except two were bilateral; Gruner et $a l^{11}$ and Gutowski et $a l^{7}$ described patients with left-sided unilateral softening. Here we report a case of infarction in the unilateral posterior horn and lateral column of the lumbar cord, with spared posterior columns.

Neurology, Faculty of Medicine, University of Tokyo, 7-3-1

Hongo, Bunkyo-ku, Tokyo, 113, Japan $M$ Kaneki

$\mathrm{K}$ Inoue

T Shimizu

T Mannen

Correspondence to: Masao Kaneki, Department of Geriatrics, Faculty of Medicine, University of Tokyo, 7-3-1 Hongo, 113, Japan.

Received 13 March 1993 and in revised form 13 July 1993

Accepted 21 July 1993

\section{Case report}

A 49-year-old woman was admitted to our department on 15 March 1988 because of pain, sensory disturbance, and muscle weakness in her left leg. The patient had first noticed lower back pain on $8 \mathrm{March}$. The next day she noticed severe pain and weakness in her leg after climbing stairs. These symptoms improved gradually before admission. At the time of admission, her blood pressure was $158 / 86 \mathrm{mmHg}$ and general physical examination showed no abnormalities except for a mild systolic murmur (Levine grade II/VI) and mild hypertensive changes of the optic fundi (Keith-Wagener grade I). Neurological examination disclosed monoparesis with pyramidal signs and a segemental superficial sensory disturbance in her left leg (fig 1). There was no muscle atrophy or fasciculation and nerve stretch tests were negative. She could walk independently, but with a limp. On her left side the patellar tendon reflex was diminished, the Achilles tendon reflex was hyperactive, and Babinski's sign was present. The patient also complained of mild urinary retention. Global anaesthesia was present in the L3 dermatome, which was surrounded by a region of analgesia (fig 1) and there was a slight diminution of superficial sensation with dysaesthesia or paraesthesia in the L1 to S3 dermatomes of the left leg. Vibratory sense was normal bilaterally at the patella, medial malleolus, and metatarsophalangeal joints. Other forms of deep sensibility such as proprioception and skin writing were normal, except in the left L3 dermatome. Routine laboratory tests were normal, as was the composition of cerebrospinal fluid on the third day. Plain radiographs of the spine, myelography, and needle electromyography

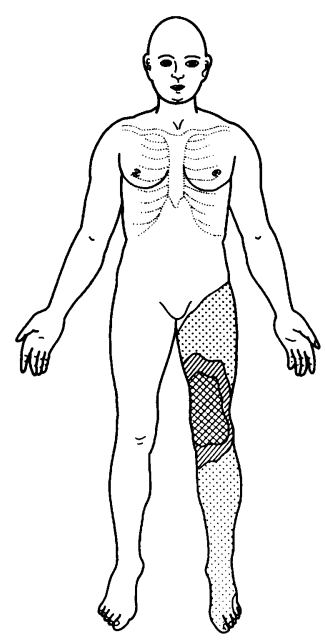

Figure 1 Distribution of sensory disturbance 10 dals after onset. The area of grid, considcred to be the $L, 3$ dermatome, showed anacsthesia. The hatchid portion surrounding the area of grid showed analgesia; the dottid area hypoalgesia. 
Figure 2 T2-weighted MRI by Siemens

Magnetome 1.5 tesla

(TR:3.0 s, TE:90 ms).

(A) T2-weighted image seven days after onset.

There is a focal high

intensity lesion in the left posterolateral region of the cord. Most of the high intensity lesion is considered attributable to concomitant oedema. (B) T2-weighted image 74 days after onset, at the same level as $(A)$. The high intensity lesion was greatly diminished and seemed to be confined to the region of the posterior root entry zone.
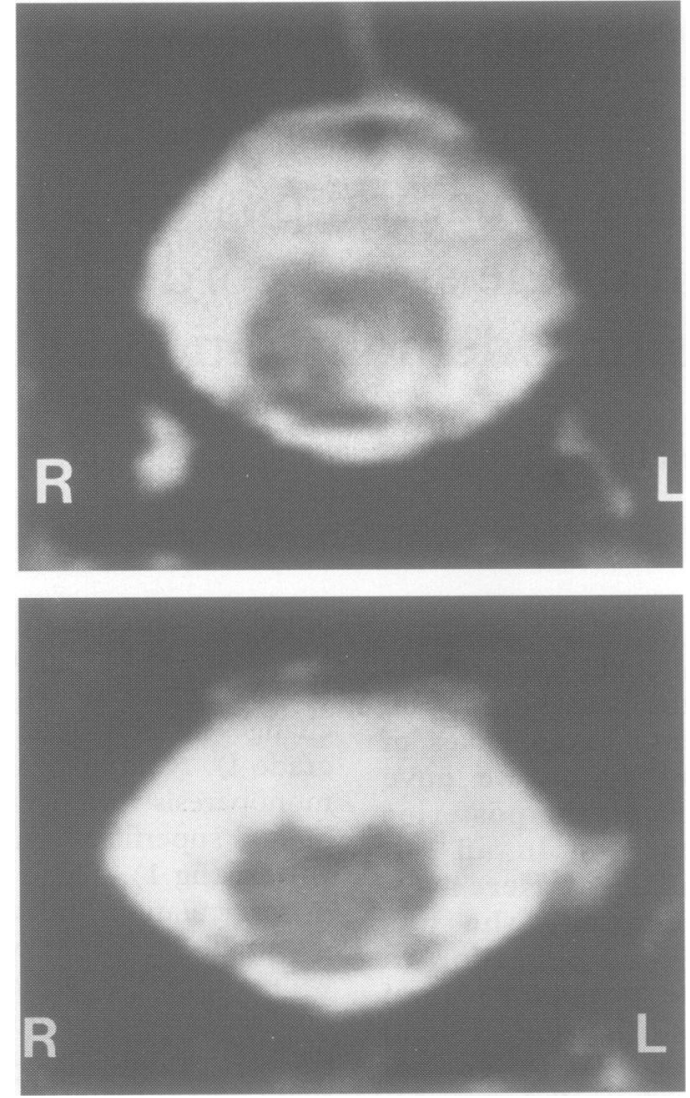

showed no abnormalities. Abdominal aortography showed that the great anterior radicular artery of Adamkiewicz originated at the left L2 root level and was patent. There was no abnormal vasculature or mass. Seven days after the onset, MRI showed a focal lesion with a high signal intensity on $\mathrm{T} 2$-weighted images in the left posterolateral region of the cord (fig 2A), which was centred on L3 with rostral and caudal extension of about $2.5 \mathrm{~cm}$ in length. T1-weighted images showed a slight low intensity lesion, but the contrast was so mild that visualisation was difficult. Gadolinium DTPA enhancement was not performed. Thirty one days after the onset, MRI showed the lesion to be much smaller. The patient's monoparesis had improved, but total loss of all sensation in the L3 dermatome remained. Urinary retention resolved spontaneously. The findings of the third MRI performed 74 days after the onset were identical to those of the second MRI performed after 31 days (fig 2B). No new features developed during the next five years.

\section{Discussicn}

The diagnosis of the spinal cord infarction in the distribution of the posterior spinal arteries was made on the basis of clinical presentation and MRI findings. In this case, the lesion was unilateral on the left side with involvement of the left posterior horn and posterior part of the left lateral column, including the lateral corticospinal tract. The spinothalamic tracts and the anterior horns were not involved and the posterior columns were spared. This area is in the region of the posterior spinal arteries because the anterior horns, which are the parts of the cord most vulnerable to insufficiency of the anterior spinal arteries, were not affected.

As far as we know, this is the first report of a case of infarction in the distribution of the posterior spinal arteries with no involvement of the posterior columns. Yoss presented an experimental model of this condition in monkeys. ${ }^{20}$ The blood supply of the spinal cord of monkeys is essentially the same as in humans. ${ }^{21}$ When the posterior spinal arteries were occluded bilaterally for a distance of 1.0 $\mathrm{cm}$ by electrocautery, both the posterior columns and posterior portion of the lateral columns were bilaterally softened. When arterial occlusions were for $5 \mathrm{~mm}$, degeneration was primarily in the posterior portion of the lateral columns and the posterior columns were spared. The posterior columns seem to be resistant to ischaemia because of their abundant anastomotic network. Our case shows the presence of atypical posterior spinal softening and suggests that the lesion of atypical cases can be detected by MRI more often than previously appreciated.

We do not believe that this injury was caused by venous infarction because (1) venous infarction is usually haemorrhagic and extends longitudinally for some distance along the spinal cord; (2) venous infarction is usually more symptomatic and is characterised by a progressive course; and (3) the incidence of venous occlusion is much less than arterial occlusion. The lesion in this case is distinguishable from the area of watershed between the central and the peripheral circulation of the cord described by Lazorthes ${ }^{19}$ and Turnbull. ${ }^{22}$

We thank Dr $\mathbf{M}$ Sonoo for helpful discussion. We are also grateful to $S$ Kusunoki and Dr $\mathrm{K}$ Takatsuka for follow up observations of the patient.

1 Williamson RT. Spinal softening limited to the parts supplied by the posterior arterial system of the cord. Lancet $1895 ; 2 \cdot 520-1$.

2 Chung MF. Thrombosis of the spinal vessels in sudden syphilitic paraplegia. Arch Neurol Psychiatry 1926;16: 761-71.

3 Stone L, Roback HN. Myelomalacia without thrombosis following indirect trauma (strain). $¥ A M A$ 1937;108: following ind

4 Garland H, Greenberg J, Harriman DGF. Infarction of the spinal cord. Brain 1966;89:645-62.

5 Hughes JT. Thrombosis of posterior spinal arteries. Neurology (Minneapolis) 1970;20:659-64.

6 Hegedüs $\mathrm{K}$, Fekete I. Case report of infarction in the region of the posterior spinal arteries. Eur Arch Psych Neurol Sci 1984;234:281-4.

7 Gutowski NJ, Murphy RP, Beale DJ. Unilateral upper cervical posterior spinal artery syndrome following sneeze. 7 Neurol Neurosurg Psychiatry 1992;55:841-3.

8 Schott B, Cotte L, Tommasi M. Ramollissement spinal postérieur en D7-D8 par myélome osseux plasmocytaire D11-L1. Rev Neurol (Paris) 1959;101:16-27.

9 Perier Existe-t-il un syndrome des artères spinales postérieures? Rev Neurol (Paris) 1960;103:396-409.

0 Demanet JC, Dustin P Jr, Perier O. Ramollissement de la moelle par embolisation de cris
Rev Belge Pathol 1961;27:347-58.

11 Gruner J, Lapresle J. Etude anatomo-pathologique des médullopathies d'orgine vasculaire. Rev Neurol (Paris) médullopathies d'o

12 Samson M, Forthomme J. Observation anatomo = clinique d'un ramollissement médullaire cervical dans le territoire spinal postérieur. Rev Neurol (Paris) 1962 107:371-5.

13 Garcin R, Godlewski S, Rondot P. Étude clinique des médullopathies d'orgin vasculaire. Rev Neurol 1962;106: 558-91. 
14 Hinrichs U. Myelodegeratio non specifica bei Luikern. Dtsch Z Nervenheilkd 1928;10:1-12

15 Hetzel H. Der thrombotische Verschluß der Arteria radiculais ventralis, der Arteria spinalis anterior und der Arteria spinalis posterior. Dtsch Z Mervenheilkd 1960 180:301-16.

16 Budka H, Perneczky A, Pusch St. Bandsheibengewebsembolien in Spinalgefäßen als Ursache von Myelomalazien vorwiegend in Spinalis-posteriorVersorgungsgebieten. Wien Klin Wochenschr 1979;91:

17 Toyokura Y, Mannen T. Patho-anatomical aspects of the spinal vascular lesions in the aged. Clin Neurol 1967;7: 424-31.

18 Takahashi K, Nakamura H, Wakutani K, Ashida Y,
Fukuda M. The vascular lesion of the spinal cord. Clin Neurol 1966;6:227-32.

19 Lazorthes G. Pathology, classification, and clinical aspects of vascular diseases of the spinal cord. In: Vinken PJ, Bruyn GW, eds. Handbook of clinical neurology. vol 12 Amsterdam: North Holland, 1972:492-506.

20 Yoss RE Vascular supply of the spinal cord: the production of vascular syndromes. Univ Michigan Med Bull 1950;16:333-45.

21 Sahs AL. Vascular supply of the monkey's spinal cord. f Comp Neurol 1942;76:403-15.

22 Turnbull IM. Blood supply of the spinal cord. In: Vinken PJ, Bruyn GW, eds. Handbook of clinical neurology. vol 12. Amsterdam: North Holland, 1972: 478-91.

\section{NEUROLOGY IN LITERATURE}

\section{Epilepsy}

Much has been written of epilepsy in literature, not least by Dostoyevsky. ${ }^{1}$ Early accounts, for example by Dickens, stressed the forces underlying the condition, a conclusion underpinned by medical writings of the period-for example, those of Romberg and Gowers. ${ }^{2}$ Dostoyevsky, Bennett, and Proust all refer to a particular facial expression that declares the disease. Dostoyevsky describes the unearthly scream that may usher in a tonic-clonic seizure, together with the mystical, intensely pleasurable state that some patients with complex partial seizures experience. Descriptions of the tonic and clonic phases of an attack are common as are accounts of focal symptoms after an event, indicative, as we now know, of a focal basis for the seizure. The twin sisters in Titus Groan both appear to have suffered an infantile hemiplegia although they appear confused as to its lateralisation. Déjà-vu is an experience all of us share and there is nothing in David Copperfield's history to suggest it had an epileptic basis. Wolf Solent's olfactory and gustatory hallucinations must surely be epileptic, though that diagnosis is not considered in Powys's book.

Charles Dickens, 1837-9, Oliver Twist

... and in whom all evil passions, vice, and profligacy, festered, till they found a vent in a hideous disease which has made your face an index even to your mind.

Charles Dickens, 1843-4, Martin Chuzzlewit

He spoke to them in something of his own voice too, but sharpened and made hollow, like a dead man's face. What he would have said, God knows. He seemed to utter words, but they were such as man had never heard. And this was the most fearful circumstance of all, to see him standing there, gabbling in an unearthly tongue.

Charles Dickens, 1849-50, David Copperfield

"We have all some experience of a feeling, that comes over us occasionally, of what we are saying and doing having been said and done before, in a remote timeof our having been surrounded, dim ages ago, by the same faces, objects, and circumstances-of our knowing perfectly what will be said next, as if we suddenly remembered it!"

Fedor Dostoyevsky, 1869, The idiot

Something of that strange expression which makes people realise at the first glance that they are dealing with an epileptic.

... the first sound of the dreadful scream, which burst from his chest of its own accord and which he could have done nothing to suppress.

Fedor Dostoyevsky, 1871, The devils

There are seconds-they come five or six at a timewhen you suddenly feel the presence of eternal harmony in all its fullness. It is nothing earthly. I don't mean that it is heavenly, but a man in his earthly semblance can't endure it. $\mathrm{He}$ has to undergo a physical change or die . . . in those five seconds I live through a lifetime, and I am ready to give my life for them, for it's worth it . . .

\section{Arnold Bennett, 1911, Hilda Lessways}

Idiotic greenish face . . . apelike eyes.

Marcel Proust, 1920, 1921, 1922, Remembrance of things past, vol. 2.

... with the impassive expression of an epileptic.

\section{Thomas Mann, 1924, The magic mountain}

... and one day, while the meal was in full swing, the man was seized with a violent epileptic fit, and with that oft-described demoniac unearthly shriek fell to the floor, where he lay beside his chair, striking about him with dreadfully distorted arms and legs.

\section{Fohn Cowper Powys, 1929, Wolf Solent}

Once more the scent of pinks came quivering through his brain and he felt a shameless twirl of pleasure. This time, instead of the wraith of Christie Malakite it was the body of the hatter that associated itself with that remembered scent-not any repulsive odour of mortality emerging from those nailed-up boards, but rather some spiritual essence from the presence of Death itself. And as he breathed this air, the voices of his companions became a vague humming in his ears, and all manner of queer detached memories floated in upon him. He felt himself to be walking alone along some high white road bordered by waving grasses and patches of yellow rock-rose. There was a town far below him, at the bottom of a green valley-a mass of huddled grey roofs among meadows and streamround which the twilight was darkening. Along with all this he was conscious of the taste of a peculiar kind of baker's bread, such as used to be sold at a shop in Dorchester, where as a child, they would take him for tea during summer jaunts from Weymouth.

\section{Mervyn Peake, 1946, Titus Groan}

You see, my poor child, I and my sister Cora are a great deal older than you and we both had convulsions when we were about your age. You may have noticed that our left arms are rather stiff and our left legs, too ... "Not only our left arms", Clarice broke in, "but all down our left-hand sides and our right-hand legs, too." G D PERKIN
Regional Neurosciences Centre, Charing Cross Hospital, London W6 8RF, UK

1 Pierce Clark L. A study of the epilepsy of Dostojewsky. Boston Med Surg f 1919;172:46-51.

2 Gowers WR. A manual of diseases of the nervous system, 2nd edn, 1893. 